IZA DP No. 10127

Charitable Donations by China's Private Enterprises

Björn Gustafsson

Xiuna Yang

Gang Shuge

Dai Jianzhong

August 2016

Forschungsinstitut zur Zukunft der Arbeit Institute for the Study of Labor 


\title{
Charitable Donations by China's Private Enterprises
}

\author{
Björn Gustafsson \\ University of Gothenburg and IZA
}

\author{
Xiuna Yang \\ China Development Research Foundation \\ Gang Shuge \\ Beijing Academy of Social Sciences \\ Dai Jianzhong \\ Beijing Academy of Social Sciences
}
Discussion Paper No. 10127
August 2016

\author{
IZA \\ P.O. Box 7240 \\ 53072 Bonn \\ Germany \\ Phone: +49-228-3894-0 \\ Fax: +49-228-3894-180 \\ E-mail: iza@iza.org
}

\begin{abstract}
Any opinions expressed here are those of the author(s) and not those of IZA. Research published in this series may include views on policy, but the institute itself takes no institutional policy positions. The IZA research network is committed to the IZA Guiding Principles of Research Integrity.

The Institute for the Study of Labor (IZA) in Bonn is a local and virtual international research center and a place of communication between science, politics and business. IZA is an independent nonprofit organization supported by Deutsche Post Foundation. The center is associated with the University of Bonn and offers a stimulating research environment through its international network, workshops and conferences, data service, project support, research visits and doctoral program. IZA engages in (i) original and internationally competitive research in all fields of labor economics, (ii) development of policy concepts, and (iii) dissemination of research results and concepts to the interested public.
\end{abstract}

IZA Discussion Papers often represent preliminary work and are circulated to encourage discussion. Citation of such a paper should account for its provisional character. A revised version may be available directly from the author. 


\section{ABSTRACT}

\section{Charitable Donations by China's Private Enterprises*}

The number of private enterprises in China has grown rapidly, and donations from them are an important source of philanthropy in China today. This paper investigates donations given in 2011 by private enterprises using a survey of data covering all 31 provincial-level units of China. The data show that philanthropy practised by Chinese private enterprises is widespread, but the amounts of donations are unequally distributed. Furthermore, donations are positively related to a company's profit and in most cases also to the owner's political participation as expressed in membership in the People's Congress (PC) as well as the Chinese People's Political Consultative Conference (CPPCC) at different levels. Donating is also positively related to the presence of a branch of the Communist Party of China and a trade union within the firm. In contrast, there is little support for donations being related to the characteristics of the major owner in the business, such as their gender, age, previous employment experience, party membership or to the governance structure or location of the private firms.

JEL Classification: D64, H84, L26

Keywords: China, philanthropy, donations, private enterprises

Corresponding author:

Björn Gustafsson

Department of Social Work

University of Gothenburg

P.O. Box 720

SE 40530 Göteborg

Sweden

E-mail: Bjorn.Gustafsson@socwork.gu.se

\footnotetext{
* This work was supported by a grant from the Swedish Research Council - the Swedish Research Links Program. Much of the work by Xiuna Yang was carried out when she was a visiting PhD student at the University of Gothenburg and funded by a grant from the China Scholarship Council (CSC).
} 


\section{Introduction}

As China has grown, it has witnessed a large rise in the private sector, and now private entrepreneurial activities in China are embedded into the very fabric of society. Through their activities, China's private enterprises acquire profits, much of which are used for further investment or utilized by business owners to fund their private consumption. However, some of the income is donated to charity and contributes to China's charitable sector, which consequently has expanded from a low level over the past three decades.

Donating behaviour can be looked at from several perspectives. One perspective is that donating behaviour is influenced by the existence of excess resources available to sponsors to donate, and thus it arises from the unequal distribution of income in society. Another perspective is that the needs for donations vary across time, due to factors such as the occurrence of disasters or specific events, and this influence for example volumes of donations. Still another perspective relates to the availability of suitable channels for transferring donations to the recipients, which can be influenced by public policies. Although people might donate for altruistic purposes, there can also be ulterior motives and circumstances, such as to gain favour in terms of economic benefits, and donations might even be done under pressure from peers and organizations; it is this perspective that is developed further and assessed in this paper. ${ }^{1}$

This paper attempts to contribute to the growing literature on donations by private firms in China by asking two research questions: First, does political participation as expressed in membership in the People's Congress (PC) as well as the Chinese People's Political Consultative Conference (CPPCC) in China - positively related to the donating behaviour of private business owners? Second, is the existence of a branch of the Communist Party of China (CPC) and/or a trade union at the firm positively related to donations?

Our study is one in a tradition of studying charitable donations made by private enterprises in China and was carried out by analysing survey data on private enterprises and their main owner. Our study differs, however, from the previous studies in several respects: First, we have a unique focus in our research questions. Second, the empirical strategy we apply makes it possible to investigate the various dimensions involved in the making of donations: not only factors relating to how much a firm donates, but also

\footnotetext{
${ }^{1}$ For surveys on the literature on donations see Andreoni (2006) and Bekkers and Wiepking (2007).
} 
relating to whether or not a private firm will make donations as well as the factors that relate to the size of any donation conditioned on the premise that a donation takes place. Third, the data refers to the survey for 2011, which is more recent than the datasets used in previous studies, and also has the advantage that the question on donations is more precise, as respondents were asked for the value of donations made during the preceding year, not - as in earlier surveys - during an unspecified period in the past. Finally, we consider that the survey consisted of two sub-samples, and so our statistical analysis includes separate estimations using three equations for each of the two samples.

The data we use shows that making donations is a widespread practice among China's enterprises. Not surprisingly we found that the amounts donated are positively related to the profits of the donating firm. On average, the amounts donated account for ten percent of a private firm's profits. Furthermore, the amounts donated were found to be rather unequally distributed, as some private firms did not make donations during 2011 while others donated relatively large sums.

The statistical analysis shows that a business owner's participation as expressed by membership in the People's Congress (PC) as well as the Chinese People's Political Consultative Conference (CPPCC) at different levels is positively related to the firms' donating behaviour. We also found that the propensity for a firm to make donations was positively related to the presence of a branch of the Communist Party of China as well as a trade union within the firm. In contrast there is little support for donations being related to specific characteristics of the private owners themselves, such as their gender, age, previous employment experience or party membership, or to the governance structure of the private firms or the location of the firms.

The remainder of the paper is structured as follows: Section 2 provides some background information relating to the increased number of Chinese private firms; Section 3 explores the role of donations in China; Section 4 discusses the research literature on donations by private firms in China; Section 5 reports on the survey data and on China's private entrepreneurs and their firms; Section 6 describes the size and distribution of donations given by private enterprises; Section 7 reports the results from estimating models that relate various dimensions of donations to variables measuring profits, personal characteristics and the characteristics of the company; and, lastly, Section 8 summarizes the findings of the paper. 


\section{China's private firms}

In the 1950s and some decades thereafter, almost all economic activity in China took place among state-owned enterprises (SOEs), collective enterprises and People's communes, while the private sector nearly disappeared. As is well known, this scenario has changed dramatically. Communes now belong to history and agriculture is nowadays a household activity. As the SOEs and collective enterprises underwent major reform during the second half of the 1990s and some years thereafter many workers were laid off. At the same time, ever-increasing numbers of individuals started to register themselves as self-employed ( $g$ e $t i h u$ ) or as private business owners (si ying qi ye zhu) employing others. The latter possibility was legally established in 1988 and involves registering at the State Administration for Industry and Commerce (SAIC) at different levels. ${ }^{2}$ At the end of 2011 (the reference year of our survey), no less than 104 million workers were employed in private firms, with this number increasing to 125 million in 2013.

China's private companies operate in most production sectors of the economy. The majority can be classified as family firms, while others rely to a large extent on funds from shareholders or lenders. From this, it follows that private companies' governance structures differ from each other. The activities of limited-share companies, a subset of all private enterprises, are regulated by the Company Law of the People's Republic of China. ${ }^{3}$ Such companies have a board of directors that regularly oversees the activities of the firm. Company Law also stipulates that limited-share companies should have a board of supervisors in which staff representatives are also appointed. Variation also exists among privately owned firms regarding other formal influences of the workers on management. Some have a trade union, while others do not, some have a local branch of the Communist Party, while others do not.

While the opportunities to operate private firms in present-day P.R. China are better than in the past in many respects, it should be acknowledged that private businesses in China still face challenges. It is typically not easy for a private enterprise to access capital via the formal credit market for starting up or for expanding the business. Often , a private firm has to rely on funds from family and friends of the largest or sole owner. Other alternatives are trade credits - various types of funding provided by private trade agencies - as well as retained earnings (Haggard and Huang , 2008, Nee and Opper,

\footnotetext{
${ }^{2}$ See http://www.saic.gov.cn/english/ (accessed 5 May 2015).

${ }^{3}$ See http://www.china.org.cn/english/government/207344.htm (accessed 5 May 2015).
} 
2012). In the informal channels, trust, reputation and relationships with influential members of society are important. Making donations can raise a firm's standing and thereby improve a private firm's access e.g. to bank loans, as indicated by the results of Chen et al. (2015) who analysed a sample of listed Chinese firms from 2003 to 2010.

Further challenges arise from the social environment of carrying out business in China. China's legal framework has not been reformed sufficiently and rapidly enough to allow it to play a significant role in contract enforcement. To deal with administrative approval and the management of government successfully and efficiently, some of the private business owners take the strategy to try to maintain good connections with government officials.

Thus it can be seen that China's private entrepreneurs have much to gain by building social networks with government officials for example, to obtain information, support and to become more influential. This can be achieved by interacting with governmental officials and policymakers at an individual level. In addition, China's private entrepreneurs can exert influence by joining some formal institutions, e.g. by gaining membership to a political party, such as China's Communist Party (CPC, the ruling party) or one of the eight other parties (often referred to as the "democratic parties"). Since 2003, the owners of private enterprises have been officially welcomed to apply to become members of CPC, and this data indicate that a large fraction have applied and also been admitted into such (See Table 1). There are also other institutions affecting policymaking in China.

One such institution is the People's Congress (PC). ${ }^{4}$ There are PCs at different administrative level: national, provincial level etc. The National People's Congress (NPC) is the national legislature of the People's Republic of China. The NPC is elected for a term of five years. It holds annual sessions every spring, usually lasting from 10 to 14 days, and is the highest organ of state power in China. Delegates are elected via a multi-tiered representative electoral system.

Another institution is The Chinese People's Political Consultative Conference (CPPCC). "The primary functions of the CPPCC are to conduct political consultations and democratic supervision, and organize its member parties, organizations and personages from various ethnic groups and walks of life to discuss and manage state affairs. All

${ }^{4}$ See http://www.npc.gov.cn/englishnpc/about/node_2842.htm 
activities of the CPPCC are guided by the Constitution of the PRC." ${ }^{5}$ There are CPPCCs at the national, provincial unit, and city etc levels. ${ }^{6}$ The local committees are formed on the basis of local circumstances and in light of the composition of the National Committee. ${ }^{7}$

Owners of private firms who are members in PC or CPPCC are in a better position than non-members when it comes to affecting and implementing policy, and are typically more informed on such matters which in turn can positively affect their business. At the same time they are also subject to pressure from other members in those organisations to donate, while this is not the case for non-members. As stated in the introduction, this paper asks if firms with owners who are members of the PC or of the CPPCC donate more than other private firms. Pressure to donate can also come from organisations at the firm level. This paper therefore also asks if private firm with a branch of Communist Party as well as those with a trade union donate more.

\section{Donations in China}

After the founding of the People's Republic of China in 1949 - with socialist ownership and a planned economy - there was very little scope for organizing private donations in China, and the institutions receiving and distributing donations thus gradually declined. According to Liu (2011), the remarkable recovery and subsequent development that took place thereafter can be divided into different stages which correspond to the process of the transition of government functions and the development of a civic society. For example, the period between 1978 and 1992 marked an expansion stage. This period witnessed the introduction of tax reductions for charity donations given by enterprises and the establishment of China's Charity Federation (CCF). ${ }^{8}$ CCF was established from the top down through the support and interactions of the party state but formally has not a governmental status.

\footnotetext{
${ }^{5}$ See http://www.china.org.cn/english/archiveen/27750.htm

${ }^{6}$ See http://www.china.org.cn/english/features/55312.htm

${ }^{7}$ For further details see http://www.cppcc.gov.cn/zXww/2012/07/03/ARTI1341301557187103.shtml

${ }^{8}$ http://cszh.mca.gov.cn/article/english/ (accessed 5 May 2015)
} 
In China, the de facto boundary between the government and charity organizations is often hard to determine. ${ }^{9}$ Many donations in China are also channelled through the government, Red Cross Societies or through private funds. The latter can be funded by a major gift from a wealthy person or firm, and their number has expanded rapidly since 2004 when a new legal framework first came in place. ${ }^{10}$

One important underlying reason for the expansion of giving and philanthropy in China is a rapid expansion in the number of wealthy people and their increasingly large resources. Many new rich individuals are private business owners who can afford for their company to make donations. For example, the number of private enterprises in China increased from 1.76 million in 2000 to 10.86 million in 2012 and 16.54 million in April 2015. ${ }^{11}$ While it is far from true that all private business owners are rich, it is also true that China's rich private owners comprise the majority of the rich. According to official statistics, the total amount of donations giving by private firms is larger than that donated by other types of corporations or from private households. ${ }^{12}$

For the private entrepreneurs, apart from donations made for purely altruistic motives, donations can help to build good relations with the government and can improve the public status of private entrepreneurs (Dickson, 2003). Such improved status can be helpful when dealing with officials, e.g. private business may be given a "helping hand" rather than a "grabbing hand", and in this indirect way, private business activity can be promoted. In addition, private donation can earn political rewards for the owner of the private firm and can even facilitate their political participation. Moreover, some wealthy individuals are alumni from well-known Chinese universities and donate large sums to their alma mater. In contemporary China, donations are used for many purposes and are often associated with historical events. ${ }^{13}$ For example, natural disasters such as the

\footnotetext{
${ }^{9}$ Hui (2011) shows how various stakeholders have different views on need of reform in the CCF.

10 See Feng (2013) and Lai et al (2015). Information on Chinas Private Foundations can also be found on http://en.foundationcenter.org.cn/online.html (Accessed 2015-12-21)

11 These numbers are from Chinese Private Economy Yearbook (2006), Chinese Economy and Trade Yearbook (2013) the National Report for the Development of Market Entry (2015). . According to the Hurun Report (2013) there are now 64,500 super-rich persons in China, half of whom own a private company, and there are 8,100 billionaires, of whom 80 per cent are private business owners.

12 According to the Annual Report on China's Philanthropy Development (2012), the total amount of donations from private companies accounted for 64 per cent of the amount donated by all kinds of enterprises to earthquake relief funds in 2008. In 2011, donations by private enterprises represented 57.9 per cent of all corporate donations. See also Schrader and Zhang (2012, p 29), who report charitable donations by recipient type.

13 The law on charitable trusts defines a wide set of purposes:
} 
devastating 2008 Wenchuan earthquake prompted many donations from Chinese firms and individuals, and the 2008 Olympic Games in Beijing also mobilized many donations.

The expansion of donations in China should also be viewed from the perspective of the changed role of the state and changes in legislation. In 1999, the Act about Donations in China (《中华人民共和国公益事业捐赠法》) regulated the giving and receiving of donations. ${ }^{14}$ This Act also allowed a tax reduction for donations. The reform of the Enterprise Income Tax Law of the People's Republic of China in 2007 further increased the incentives for firms and individuals to donate. Since then, tax deductions can be applied to donations, up to 12 per cent of profits. ${ }^{15}$ However, as the procedure for applying for tax exemptions is overly complicated, it often hinders enterprises from claiming these tax exemptions (see Wang, 2014). After a decade of discussions in March 2016 China adopted its first law on Charity regulating charitable activities including tax treatments. ${ }^{16}$

According to the Chinese Civil Affairs' Statistical Yearbook (2014, pp. 24-25), the total sum of donations reached 56.6 billion yuan in 2013 , which is equal to 0.1 per cent of China's GDP.

\section{Literature review}

To date, empirical studies on donations in contemporary China can be categorized into two groups. The first is a non-homogeneous category that investigates charitable giving by corporations with different types of ownership. One example is Shan et al. (2008), who studied corporate donations announced in the media by 1,524 A-share firms following the 12 May 2008 earthquake in Wenchuan, Sichuan Province, focusing on the economic incentives to give. Their main finding was that firms selling products directly

http://english.gov.cn/laws/2005-09/12/content_31194.htm (accessed 5 May 2015).

${ }^{14}$ Based on this Act, the Interim Measures of Tax Exemption for the Import on Poverty Alleviation, Charitable Donations (《扶贫、慈善性捐赠物资免征进口税收暂行办法》) was created to coordinate tax treatments and charitable donations and to encourage donations from both individuals and enterprises; see the Enterprise Income Tax Law of the People's Republic of China (《中华人民共和国企业所得税法》) and the Individual Income Tax Law of the People's Republic of China (《中华人民共和国个人所得税

法》) for the specific terms of the preferential tax policy for donations.

${ }^{15}$ Previously exemptions could be made for donations amounting up to 3 per cent of profits.

${ }^{16}$ See Xinhua (2016) 
to consumers donated 50 per cent higher sums than other firms. As donations typically are made public, the results indicate that giving can be seen as an investment in consumer goodwill that can pay dividends later via increased sales revenue. Also, Liu (2013) studied corporate giving after the Wenchuan earthquake, comparing local Chinese enterprises with foreign-owned enterprises. Data on donations was extracted from reports accessed from the Internet. The study concluded that local enterprises which are most likely concerned about public opinion - donated more than foreign-owned enterprises. A third example is provided by the study by Du et al. (2010), which investigated the relationship between donations and political connections among listed companies. ${ }^{17}$ Their main finding was that political connection has a statistically significant positive correlation with charitable giving. A fourth study is that of Zhou and $\mathrm{Hu}$ (2015), who studied the charitable giving behaviour of private business owners in Wenzhou using data collected in 2011 and who reported that owners with religious believes and those taking part in religious activities tend to donate more than others. This study also reported that the existence of a party organization at the firm level affects donation behaviour.

A second category of research studies on charitable giving in China is more homogeneous in the sense that all of the studies focused on giving by private enterprises. They are all based on surveys of China's private enterprises. Being based on cross section data those studies can show statistical associations which must not necessary mean causality. Probably, the first example is the study by Ma and Parish (2006), who analysed the 1995 survey data. The results showed that as many as 87 percent of the private firms had made a donation in the past, and the authors concluded that the level of giving appeared to be exceptionally high in the light of their international experience. ${ }^{18}$ The authors suggest that this can be understood within the context of a lack of open political elections in which entrepreneurs can influence policy, as well as the fact that bureaucratic relations are uncertain. A second example is the study by Chen and Touve (2011), which used the 2004 survey of private enterprises. Here, the authors established a positive association between, on the one hand, a business owner's membership in CCP and donations and, on the other hand, the owner's membership in the People's Congress. ${ }^{19}$ A third example is the study by Jun and Jia (2010), who

\footnotetext{
${ }^{17}$ The study used data from RESSET (http://www.resset.cn/cn/) and CSMAR (http://www.gtarsc.com/) for the period 2004-2006, with 172 observations.

${ }^{18}$ We do not agree with this assessment. The 1995 survey included a question on donations given not related to a specific time period, so it is possible that respondents may have provided an answer that referred to accumulated donations given over more than one year.

${ }^{19}$ In Chen and Touve (2011), donations is an independent variable, while in our study donations is the dependent variable. Chan and Touve (2011) analyzed the 2002 survey pooling observations sampled by ACFIC and ASIC, while we analyzed the survey for 2011 and treated each sub-sample separately.
} 
analysed the 2006 survey to determine the relationship between the profitability of a company and its charitable giving, finding a positive relationship (as we also find). This result highlights that philanthropy is an important means of affording property rights protection and building political connections that can help private enterprises gain access to, for example, credit. A fourth example is the study by Gao et al. (2012), who analysed the factors that motivate private companies to make charitable donations. The authors conclude that private firms utilize charitable giving as a "fig leaf" to cover a lack of corporate social responsibility and thus to instrumentally serve their firms. Among several results, we note that private firms with trade unions donate more than those without trade unions (as we also find).

\section{Data}

The data used in this study was collected in The Tenth National Sample Survey on China's Private Enterprises during spring 2012 by the All-China Federation of Industry and Commerce (ACFIC) and the State Administration of Industrial and Commercial (SAIC). The survey is part of a series of surveys on private enterprises conducted since the start of the 1990s. The survey respondents were the main capital provider or the main investor (owner, 主要投资者) of each private firm. The information relating to our focus variable - the sum of donations - refers to the previous year (2011).

The survey covered all 31 provincial-level units (provinces, autonomous regions and municipalities directly under the central Chinese government) of the People's Republic of China. It targeted private enterprises (si ying qi ye) with eight or more employees. Of the total number of respondents, 57.3 per cent were sampled via the ACFIC, while the remaining 42.7 per cent were selected via the SAIC at a local level in a two-stage sampling process. There was only a partial overlap of the two populations. While the ACFIC sample comprised relatively large firms, the SAIC sample comprised many relatively small firms. Furthermore, the sampling strategy was not the same for the two populations. For these reasons, we treated the two samples separately.

A number of Chinese organizations and their personnel were involved in designing the questionnaires and carrying out the fieldwork. A few researchers from the Chinese Academy of Social Sciences and the Beijing Academy of Social Sciences were involved in the entire research process. There is no other regularly conducted survey of private enterprises covering all of China that can be used for academic research. The sample at our disposal consisted of 5,073 observations and, after reducing the dataset by deleting a 
few observations with implausible values on the key variables for donations as well as observations with negative profits (512) or zero (170) as well as those with missing information on profits (449), a sample of 3,942 observations remained.

Table 1 details some characteristics about the main owners of private enterprises based on our data. It can be seen that most private entrepreneurs are male. Also, most are middle-aged, with about half of them aged 40-50 years. Most of the business owners had studied in college or university in the past. In the survey, each respondent could specify up to three previous occupations they had had before becoming a private owner. From Table 1, it can be seen that about half reported having managerial experience and about one in four reporting having previously been self-employed. Some respondents had had experience of being a cadre (a public official holding a responsible or managerial position in party or government), while less than one in ten stated that they had formerly been employed as a farmer.

/Table 1 about here/

Chinese private entrepreneurs have links with politics in different ways. Our data shows that at least two out of five entrepreneurs in the ACFIC sample and one in four in the SAIC sample are members of the Communist Party of China (CPC). Much fewer private owners belong to one of the democratic parties. Besides party membership, many Chinese business owners are members of the People's Congress or the Chinese People's Political Consultative Conference at different levels. Such memberships are more common in the ACFIC sample, where a majority of business owners are members of one of the organizations compared to in the SAIC sample. In the Appendix, we cross-tabulate private owners by party membership/non-membership and membership in the PC as well as in CPPCC. The tables show, for example, that among the PC members 57 per cent are also CPC members.

/Table 2 about here/

Table 2 details the characteristics of Chinese private companies and their governance structures. Overall, companies in the ACFIC sample employed a higher number of workers and showed higher profit levels. The median number of workers was 87 in the ACFIC sample, but only 12 in the SAIC sample. The mean value is much higher than the median value for the number of employees in both samples, indicating that each 
sample included a large number of small companies and few large companies. Profits were found to be much higher in the ACFIC sample, as were the taxes paid. ${ }^{20}$ The proportion of private firms registered before 1991 was found to be very small for both samples. A Communist Party organization was found to be present in half of the firms in the ACFIC sample, yet in only one out of six firms in the SAIC sample. In two-thirds of the firms in the ACFIC sample, a trade union branch was reported to be present, but this was the case in only one in four companies in the SAIC sample.

Private enterprises operate in various production sectors. Approximately three-quarters of the private firms can be classified as family firms. Looking at the governance structure in the ACFIC sample, about half have shareholder meetings, while this was found to be the case in only a quarter of firms in the SAIC sample. Two-thirds of the firms in the ACFIC sample were reported to have a board of directors, compared with slightly less than half in the SAIC sample. One-third of the firms in both samples were found to have a board of supervisors.

\section{Donations by private firms}

/Table 3 about here/

Private donations in the present study refer to money and goods donated by Chinese private firms for purposes that include poverty alleviation, disaster relief, environmental protection, and education and so on. Donations are given in cash as well as in goods; in the survey, the latter were reported to be converted into their market value by respondents. As many as 82 per cent of companies in the ACFIC sample made some donations in 2011, but this proportion was only 41 per cent in the SAIC sample. This is shown in Table 3, while Figure 1 presents the cumulative amount of donations. The curve for the SAIC sample starts higher up the vertical axis. The median donation for the ACFIC sample was 30000 yuan. A comparison with the amounts of taxes paid by the privately owned firms, as reported in Table 2, show that on average donations are considerably smaller than taxes, an illustration of China's civil society being small in relation to the size of the government. Our data show that mean donations amount to 8.5 per cent of average profits in the ACFIC sample, while the corresponding figure in the SAIC sample is 11.4 per cent. Half of firms in the ACFIC sample donated at most 2.9 per cent of profits, while the other half donated a larger proportion. The amount of

\footnotetext{
${ }^{20}$ The data showed that 95 per cent of companies in the ACFIC sample made profits, while the corresponding figure for the SAIC sample was 75 per cent.
} 
donations was found to be very unequally distributed in both samples. The data showed that in the ACFIC sample almost five per cent of companies had donated at least one million yuan. In Table 3, for each sample, no simple relationship was found between the owner's political party membership and donations. The unequal distribution of donations was indicated by the numerical value of the Gini coefficient, which was found to be 0.86 in the ACFIC sample and 0.95 in the SAIC sample.

/Figure 1 about here/

In Figure 2, we plotted for each of the sample firms by (the logarithm of) net profits and (the logarithm of) donations. Not surprisingly a positive relationship is visible for both samples. However, for a given level of profits there is also a variation indicating that additional factors are at play; our attempts to investigate these is the topic of the next section.

/Figure 2 about here/

\section{Modelling the determinants of donations}

To understand what factors were related to charitable giving, we used the following approach: We estimated three equations for each of the two samples using the same explanatory variables. A set-up of three equations has the potential to lead to a better understanding of factors related to giving compared to the alternative of working with one equation only. We also carried out one robust check by estimating alternative specifications, as reported at the end of this section.

In the first model the dependent variable was, as in much of the literature on donations, the logarithm of the amount of the donation. The model was estimated using all the observations in the sub-sample (ACFIC and SAIC, respectively). As there were several observations with zero donations, we applied the Tobit estimator. The second model was used to investigate factors that were related to giving a positive amount or not. Thus, the dependent variable was binary and we applied a Logit model. Differing from the above two models, estimation of the third model was limited to the set of private 
firms that had made positive donations. Similar to the first model, the dependent variable was the logarithm of donations, and this model was estimated using ordinary least-squares (OLS).

The following explanatory variables - described in previous sections - were used in the specifications: the logarithm of net profits during 2011, dummy variables for owners' membership of the PC, owners' membership of the CPPCC, owners' membership of the CPC, owners' membership of a Democratic Party, the existence of a CPC branch at the firm and the existence of a trade union at the firm. Control variables include the following characteristics of the major owner: gender, age (two dummy variables), education (two dummy variables) and previous occupation of the owner (seven dummy variables). Further, we included a number of characteristics of the firms: year of registration (two dummy variables), a dummy indicating family enterprise and several dummy variables for the production sector. We also applied three dummy variables for the governance structure of the company (existence of a shareholders' meeting, or a board of directors or a board of supervisors). Where information relating to a particular characteristic was missing from the survey and in order to use such observations, we included dummy variables to substitute for the missing information. To investigate whether there was a relationship between the marketization degree in the province and donations, we also included the market index of each province as developed by Fan et al. (2010). The specifications also included a string of 30 dummy variables for the province-level unit in which the firm was located.

\section{/Table 4 about here/}

The estimates are presented in Table 4 and here we provide some comments on them. We start with patterns that are clear in terms of coefficients with the same signs and that were estimated with high t-values in both the ACFIC sample and in the SAIC sample in most equations. A very clear, and hardly surprising, result is that we found a positive relationship between the company's net profit and the size of donations made. The level of profits was positively related to giving donations, as well as to the size of the donation, conditioned on the basis that donations were given. There was a general association between a business owner's membership of the PC as well as the CPPCC and the size of the donations. These results are consistent with a role of donations as discussed in Section 3 and can indicate for example that the existence of peer pressure to donate is important for charitable giving in China. ${ }^{21}$ The only exception (as seen in

\footnotetext{
${ }^{21}$ Compare this with similar results reported by Meer (2012) who analyzed giving by alumni in the United States.
} 
column 6) is in the SAIC sample, which shows that, conditioned on a donation being made, the amount of the donation is not significantly related to the business owner's membership in the PC or CPPCC.

The existence of a trade union at the firm level and donations are positively related in both samples. We also found that there was a positive association between the existence of a Communist Party organization at the firm and the donations made. In the ACFIC sample, there is also a positive relationship between the existence of a Communist Party organization and the amount of donations, conditioned on a donation having been made. In contrast there are no indications of the owner's membership in the CPC and donations being related.

Pay attention to that, there are few examples of control variables and donations being related. One is that older firms donate more than newer ones in the ACFIC sample (but not in the SAIC sample). In both samples, there is a positive relationship between the major owners previously having been self-employed and donations (but not with the amount of donations, conditioned on the donations having been made). ${ }^{22}$

\section{/Table 5/}

How robust are our findings? We answer this question by estimating an alternative specification. We exclude the province dummies as the "marketization" index by construction takes values that are identical for all firms in a province-level unit. We are worried that a possible correlation between province dummies and the "marketization" index might affect the estimates. Table 5 shows that for such a specification are the coefficients for our variables of interest in the first two equations similar as in the base specification reported in Table 4. However, when it comes to statistical significance in the third equation which relates the amount of donations to various variables some differences appear; the coefficient for CPC organization in the ACFIC sample loses statistical significance while the opposite is the case for the (positive) coefficient for Membership in CPPCC in the SAIC sample. As in the base line specification reported above, the coefficients for the variable marketization index are not statistically

\footnotetext{
${ }^{22}$ The lack of a relation between dummies indicating existence of board of directors and shareholders on meeting on one hand and donations on the other hand is consistent with what is reported from a study of manufacturing firms in the Yangzi region studied. Nee and Opper (2012, p 124) write that the shareholder meetings and board of directors form many of the companies they investigated are decoupled from the actual operation of the firm.
} 
significant in this specification. From the robust check we conclude that estimates of the third equation, which is obtained from a smaller sample compared to the first two equations, are less robust with respect to model specification.

Before ending this section some words on the limitation of the statistical analysis. It has shown the existence of several statistical relations, but as is well known correlations must not mean causality. What we have postulated as right hand side variables might in reality be affected by donations. For some of the results we report such a revised causality appear difficult to vindicate. It seems difficult to maintain that China's private firms donate to charities in order to promote the establishment of a trade union at the establishment or to promote the establishment of a branch of the Communist Party. However, when it comes to the positive relation between the firm's main owner being a member of People's Congress (PC) and in Chinese People's Political Consultative Conference (CPPCC) and donations causality can run either of both ways. This as it is as reasonable to assume that a main owner's ambition to become a member of the organisations can affect the firm's donation behaviour as to assume that membership in PC or CPPCC affect donating behaviour. It is a task for future research to shed light on which of those interpretations are most important in the Chinese context. ${ }^{23}$

\section{Conclusions}

The number of private enterprises in China has been growing rapidly and contributions made by them are an important source of philanthropy in China today. Donating behaviour can be understood from several perspectives. In this paper we have focused on economic incentives of the giver as well as pressure from peers and organizations. We have asked: Is membership of the private firm's main owner in People's Congress (PC) and in Chinese People's Political Consultative Conference (CPPCC) positively related to donations of the private firms? Secondly, is the existence of a trade union and a branch of the Communist Party at the firm positively related to donations?

We have analysed the data from a country-wide survey to explore various aspects of donations given by private enterprises in 2011. The survey consisted of two sub-samples that were not fully overlapping and which were derived in somewhat

\footnotetext{
${ }^{23}$ This would be facelifted in case the surveys of private enterprises in China had a panel design. Qualitative research interviewing main owners can also have a role to play.
} 
different ways. Given this, we analysed them separately. Our data shows that large variations exist in the size of donations given by private enterprises. Some of the private enterprises were found to have donated very large amounts while others donated much less, and some donated nothing. According to our data on average, out of 100 yuan earned as profit by China's private enterprises, approximately 10 yuan were given as donations. This is considerably less than taxes paid by private firms.

To understand which factors were related to charitable giving, we estimated multivariate models. Our strategy was to analyse each of the two sub-samples separately and apply a specification that allowed us to investigate different aspects of giving. Explanatory variables measured the owner's membership in PC and in CPPCC, the existence of a trade union and of a branch of the Communist Party at the establishment, the logarithm of net profit of the private firms as well as a number of control variables: personal characteristics of the private owner, characteristics of the firm as well as the location of the firm.

The estimates showed that different aspects of charitable giving are, not surprisingly, positively related to the net profit of the firm. Importantly, we found that the membership of private firm's major owner in the People's Congress (PC), as well as in the Chinese People's Political Consultative Conference (CPPCC) are positively related to donations. One interpretation of this is that social ties and political participation affect donating behaviour, another and not necessary conflicting is that firms donate in order to promote the main owners membership in those organisations. Donations were also positively related to pressure at an establishment level: by the existence of a branch of the Communist Party as well as by a trade union. We found no general support for the owner's membership in CPC and donations being related. Our research found little evidence of an association between donating and private owners' personal characteristics, such as gender, age, previous employment experience, nor by the governance structure and the location of the private firms. 


\section{Bibliography}

Andreoni, J., "Philanthropy" in Kolm, S.-C. and J.M. Ythier, (Eds) (2006) Handbook of Giving, Reciprocity and Altruism II (Elsevier: North Holland), Chapter 12.

Bekkers, R. and P. Wiepking, (2007), "Generosity and Philanthropy. A Literature Review”, Paper Vrije Universiteit Amsterdam . Downloaded from

https://generosityresearch.nd.edu/assets/17632/generosity_and_philanthropy_final.pdf Accessed March 12, 2015.

Chen, D., Jiang, D. and $\mathrm{Yu}, \mathrm{X}$. (2015) "Corporate Philanthropy and Bank Loans in China", Pacific-Basin Finance Journal, article in press.

Chen, Y. and D. Touve, (2011) "Conformity, political participation, and economic rewards: the case of Chinese private entrepreneurs", Asian Pacific Journal of Management, 28, (2011), pp. 529-553.

Ministry of Civil Affairs (2014) China Civil Affairs' Statistical Yearbook China Statistics Press.

Deng G., (2013) "The level of donations from wealthy people in China and the reasons for the changes", Journal of Chinese a Public Administration, 2, (2013), p. 72 (in Chinese) 邓国胜: 《中国富人捐赠水平及其变化原因》，《中国行政管理》，第 2 期，第 72 页。

Dickson, B., (2003) Red Capitalists in China. The Party, Private Entrepreneurs, and Prospects for Political Change (Cambridge: Cambridge University Press).

Du X. Q., J. Guo J. and Y. Lei, (2010) Political Connections and Donation of Private Listed Companies: Measurement Methods and Empirical Evidence, Finance Research, 1, pp. 89-99 (in Chinese). 杜兴强、郭剑花、雷宇: 《政治联系方式与民营企业捐赠 
：度量方法与经验证据》，《财贸研究》年第 1 期, 第 99 页。

Fan, G., X. Wang, and H. Zhu, (2010) NERI Index of Marketization for China's Provinces: 2009 Report (Economic Science Press, Beijing, ) (in Chinese). 樊纲、王小 鲁、朱恒鹏著: 《中国市场化指数——各地区市场化相对进程 2009 年报告》, 经 济科学出版社。

Fan G, X. Wang, H. Zhu (2010) "zhongguo shichanghua zhishu—ge diqu shichanghua xiangdui jincheng 2009 nian baogao" (in Chinese), jingji kexue chubanshe.

Feng, X. (2013) "China's Charitable Foundations: Development and Policy-Related Issues", Stanford Centre for International Development, Working Paper No. 485. Accessible at http://siepr.stanford.edu/?q=/system/files/shared/documents/485_XiaomingFeng.pdf Downloaded 20141027,

Gao Yongqiang, Chen Yajing and Zhang Yunjun, (2008) "'Red Xcarf' or 'Green Scarf': Motivation of Charitable Donation of Private Enterprises", Management World, 8, (2008), pp. 106-114 (in Chinese) 高勇强、陈亚静、张云均: 《“红领中”还是“绿领 巾”: 民营企业慈善捐赠动机研究》，《管理世界》，2008 年第 8 期, 第 106、114 页。

Haggard, S. and Huang, Y. (2008) "The Political Economy of Private-Sector Development in China, in Brandt, L and Rawski, T.G. (Eds) China's Great Economic Transformation (Cambridge: Cambridge University Press), pp. 337 - 374.

Hui, W. (2011) "Changes in the China Charity Federation System", China Development Brief.

http://chinadevelopmentbrief.cn/articles/changes-in-the-china-charity-federation-system Downloaded 20151027 
Hurun, The Chinese Wealth Report (2013). Available at

http://up.hurun.net/Humaz/201312/20131218145315550.pdf Downloaded, March 11, 2015.

Jun S, and Jia, H., (2010) "Does giving lead to getting? Evidence from Chinese private enterprises", Journal of Business Ethics, 93, pp. 73-90.

Lai, W., Zhu, J., Tao, L. and Spires, A. (2015) "Bounded by the State: Government Priorities and the Development of Private Philanthropic Foundations in China", China Quarterly, 224, 1083 - 1092.

Liu H., (2013) "Institutional environment, organizational slack and behaviors difference: An empirical study of comparison between local and foreign donors", Motivation, Management Review (in Chinese), 8, pp. 77-91. 刘海建: 《制度环境、组织圥余与捐赠 行为差异: 在华中外资企业捐赠动机对比研究》，《管理评论》，2013 年第 8 期, 第 77 页。

Liu, P., (2011) "Development of Charities in China since the Reform and Opening Up", in Li, Y. (Ed) NGOs in China and Europe, Comparisons and Contrasts (Farnham: Ashgate), pp. 71-94.

Liu, Y. L. (2012) "Report for the Charitable donations in China in 2011" in Yang T: The Annual Report on China's Philanthropy Development, Social Sciences Academic Press (CHINA). 刘佑平、李扬《2011 年中国慈善捐助报告》，第 37 页。杨团主编: 《中国慈善发展报告 2012》，社会科学文献出版社，

Ma, D. and W. Parish, (2006), "Tocquevillian moments: charitable contributions by Chinese private entrepreneurs", Social Forces, 85, , pp. 943-964.

Meer, J., (2011) "Brother, can you spare a dime? Peer pressure in charitable solicitation”, Journal of Public Economics, 95, pp. 926-941.

National Report on the Development of Market Entry (2015) available at 
http://www.saic.gov.cn/zwgk/tjzl/zhtj/xxzx/201505/P020150520619283729167.pdf

Nee, V. and S. Opper, (2012) Capitalism from Below, Markets and Institutional Change in China (Cambridge, MA: Harvard University Press),

Schrader, A and M. Zhang, (2012) Corporate Philanthropy in China. A Practitioner's Guide for Foreign Donors (The Conference Board, China Centre ). Downloaded from http://ciyuan.bsr.org/data/resources/TCB_R-1505-12-RR_pdf.pdf Accessed March 12, 2015.

Shan, L. L. Gan, L and T. Zheng, (2008), "Corporate donations and economic incentives: An empirical study based on corporate donations following the 5.12 earthquake in China", Economic Research Journal, issue 11, (2008), p. 51 (in Chinese) 山立威、甘黎、郑涛: 《公司捐款与经济动机一一汶川地震后中国上市公司捐款 的实证研究》，《经济研究》2008 年第 11 期, 第 51 页。

Statistical Yearbook for the Private Economy 2006.6 -2008.6 (2009), Beijing, China's Joint Publishing House of Industry and Commerce.

Wang, Z, (2014) Improving Philanthropy Through Legislation: The Context, Challenges and Paths (China: Social Sciences Academic Press, 2014), pp. 36-37 (in Chinese) 王振耀: 《现代慈善与社会治理: 2013 年度中国公益事业发展报告》, 社会科学文献出版 2014 年版, 第 54 页。

Wang Z,_Philanthropy and Social Governance (2014): The 2013 Annual Report of China's Charity Sector, (China: Social Sciences Academic Press) (in Chinese) 王振 耀: 《现代慈善与社会治理: 2013 年度中国公益事业发展报告》, 社会科学文献 出版 2014 年版，第 54 页。 
Wang Z (2014) Improving Philanthropy through Legislation: the Context, Challenges and Paths. Social Sciences Academic Press (CHINA ). 王振耀: 《以法促善: 中国慈 善立法现状、挑战及路径选择》，社会科学文献出版社年版,第 36-37 页。

Xinhua (2016) "China's New Charity Law Seen as Timely Boost for Spirit of Giving” Available at http://news.xinhuanet.com/english/2016-03/19/c_135204203.htm

Zhou, Y., Hu, A. (2015) "Capital with Beliefs - A Study of Charitable Donations of Private Business Owners in Wenzhou, China”, Journal of Chinese Sociology, 2:8. 
Table 1: Characteristics of China's private entrepreneurs -2011

Variables in focus

ACFIC

SAIC

$(\%)$

$(\%)$

Political party membership

Not members

Communist Party of China (CPC)

Democratic Party

Membership of the People's Congress (PC)

22.93

7.52

Membership of the Chinese People's Political

Consultative Conference (CPPCC)

37.79

9.34

Not a member of PC or CPPCC

$39.29 \quad 83.14$

\section{Control variables}

\begin{tabular}{|c|c|c|c|}
\hline & & $\begin{array}{r}\text { ACFIC } \\
(\%)\end{array}$ & $\begin{array}{r}\text { SAIC } \\
(\%)\end{array}$ \\
\hline \multirow[t]{2}{*}{ Gender } & Man & 87.16 & 78.79 \\
\hline & Woman & 12.84 & 21.21 \\
\hline \multirow[t]{3}{*}{ Age (years) } & $<=39$ & 15.93 & 32.67 \\
\hline & $40-50$ & 52.61 & 45.90 \\
\hline & $>=51$ & 31.46 & 21.43 \\
\hline \multirow[t]{3}{*}{ Education } & Short & 8.02 & 11.41 \\
\hline & Medium & 23.59 & 28.03 \\
\hline & Long & 68.39 & 60.55 \\
\hline \multirow[t]{6}{*}{ Previous occupation } & Cadre & & \\
\hline & No & 79.48 & 86.22 \\
\hline & Yes & 20.52 & 13.78 \\
\hline & Manager & & \\
\hline & No & 50.87 & 59.92 \\
\hline & Yes & 49.13 & 40.08 \\
\hline
\end{tabular}

Technician 


\section{Worker}

No

$83.04 \quad 75.48$

Yes

16.96

\section{Self-employed}

No

Yes

\section{Farmer}

No

Yes

8.88

\section{Others}

No

$87.34 \quad 84.90$

Yes

12.66

15.10

\section{Note:}

1) Source: Authors' computations from The Tenth National Sample Survey on China's Private Enterprises in 2012.

2) A long education is defined as college and university education; a medium education is defined as having at least senior high school education.

3) For the variable "Previous occupation", each respondent could provide up to three answers. 
Table 2: Characteristics of private companies and their governance structure -2011

Communist Party organization within the company

$\begin{array}{lrr}\text { Don't have } & 50.64 & 84.94 \\ \text { Have } & 49.36 & 15.06\end{array}$

Trade union within the company

Don't have

$33.79 \quad 75.48$

Have

$66.21 \quad 24.52$

\begin{tabular}{lrrr}
\hline Control variables & & \\
\hline & ACFIC & \\
& $(\%)$ & SAIC $(\%)$
\end{tabular}

Net profit of the company in 2011(unit: 10000 yuan)

$\begin{array}{lrr}\text { Mean } & 959 & 438 \\ \text { Median } & 132 & 15\end{array}$

\begin{tabular}{llrr}
\hline Production sector & Manufacturing & 43.26 & 26.35 \\
& Mining/real estate/construction & 11.67 & 13.01 \\
& Commerce and services & 23.16 & 33.41 \\
& Agriculture/forestry/animal husbandry/fishery & 7.70 & 5.46 \\
& Others & 14.22 & 21.76 \\
\hline Year of registration & 1991 or before & 2.71 & 0.49 \\
& $1992-2000$ & 39.99 & 15.84 \\
& 2001 or after & 57.30 & 83.67 \\
\hline Family enterprise & No & 21.58 & 25.74 \\
& Yes & 78.42 & 74.26 \\
\hline Shareholders meeting & Don't have & 48.38 & 74.67 \\
\hline Board of directors & Have & 51.62 & 25.33 \\
\hline & Don't have & 32.94 & 55.79 \\
& Have & 67.06 & 44.21 \\
\hline & Don't have & 67.07 & 69.99
\end{tabular}


Tax of the company in 2011 (unit: 10000 yuan)

Mean

Median

Note:

1) Source: Authors' computations from The Tenth National Sample Survey on China's Private Enterprises in 2012.

2) The commercial and services sectors include: wholesale and retail, services, accommodation and catering. The "others" sectors include: electric power, coal gas, water/transportation/finance/leasing industry/research and technology/communal facilities /education/health care/culture and sport/public administration.

3) Family-based enterprises refer to those enterprises whose ownership and power of operation belong to one person or to one family, totally or as a dominant position. 
Table 3 Donations in the year 2011 in the two samples

\begin{tabular}{|c|c|c|}
\hline & AFIC & SAIC \\
\hline \multicolumn{3}{|l|}{ The entire sample } \\
\hline Sample size & 2482 & 1,460 \\
\hline Donations larger than 0 , per cent & 75.21 & 32.58 \\
\hline Mean (Yuan) & 233353 & 44841 \\
\hline Median (Yuan) & 30000 & 0 \\
\hline Gini coefficient & 0.858 & 0.951 \\
\hline \multicolumn{3}{|l|}{ Donations by members in CPC } \\
\hline Sample size & 1145 & 485 \\
\hline Donations larger than 0 , per cent & 78.78 & 44.12 \\
\hline Mean (Yuan) & 208426 & 107,309 \\
\hline Median (Yuan) & 30000 & 0 \\
\hline \multicolumn{3}{|c|}{ Donations by members in the Democratic Party } \\
\hline Sample size & 237 & 32 \\
\hline Donations larger than 0 , per cent & 75.53 & 56.25 \\
\hline Mean (Yuan) & 364013 & 197864 \\
\hline Median (Yuan) & 50000 & 10750 \\
\hline \multicolumn{3}{|c|}{ Donations by owners not members in any party } \\
\hline Sample size & 1400 & 1509 \\
\hline Donations larger than 0 , per cent & 72.50 & 28.50 \\
\hline Mean (Yuan) & 234811 & 24045 \\
\hline Median (Yuan) & 20000 & 0 \\
\hline
\end{tabular}

Source: Authors' computations from The tenth National Sample Survey on China's Private Enterprises in 2012. 
Table 4: Estimates of models relating donations in the year 2011 to various factors

\begin{tabular}{|c|c|c|c|c|c|c|}
\hline & \multicolumn{2}{|c|}{ Tobit model } & \multicolumn{2}{|c|}{ Logit model } & \multicolumn{2}{|c|}{ OLS model } \\
\hline & $\begin{array}{l}\text { ACFIC } \\
\text { sample }\end{array}$ & $\begin{array}{l}\text { SAIC } \\
\text { sample }\end{array}$ & $\begin{array}{l}\text { ACFIC } \\
\text { sample }\end{array}$ & $\begin{array}{r}\text { SAIC } \\
\text { sample }\end{array}$ & $\begin{array}{l}\text { ACFIC } \\
\text { sample }\end{array}$ & $\begin{array}{r}\text { SAIC } \\
\text { sample }\end{array}$ \\
\hline \multicolumn{7}{|c|}{ Ln (net profit of enterprise per year) } \\
\hline \multirow[t]{2}{*}{ (unit: 10000 Yuan) } & $0.780 * * *$ & $1.269 * * *$ & $0.267 * * *$ & $0.276^{* * *}$ & $0.473 * * *$ & $0.516 * * *$ \\
\hline & $(0.058)$ & $(0.154)$ & $(0.038)$ & $(0.041)$ & $(0.024)$ & $(0.051)$ \\
\hline \multicolumn{7}{|c|}{ Political and organizational involvement } \\
\hline \multicolumn{7}{|c|}{ Membership in PC or CPPCC (omitted category: not a member of PC or CPPCC) } \\
\hline \multirow[t]{2}{*}{ Membership in PC } & $1.823 * * *$ & $3.362 * * *$ & $0.817 * * *$ & $0.960 * * *$ & $0.551 * * *$ & 0.234 \\
\hline & $(0.282)$ & $(1.005)$ & $(0.195)$ & $(0.297)$ & $(0.116)$ & $(0.281)$ \\
\hline \multicolumn{7}{|l|}{ Membership in } \\
\hline \multirow[t]{2}{*}{ СРPCC } & $2.043 * * *$ & $4.042 * * *$ & $1.080 * * *$ & $1.143 * * *$ & $0.427 * * *$ & 0.291 \\
\hline & $(0.237)$ & $(0.894)$ & $(0.156)$ & $(0.264)$ & $(0.099)$ & $(0.247)$ \\
\hline \multirow[t]{2}{*}{ Missing information } & $1.665 * * *$ & 0.535 & $0.875 * * *$ & 0.170 & -0.064 & $-0.784 *$ \\
\hline & $(0.563)$ & $(1.227)$ & $(0.334)$ & $(0.302)$ & $(0.238)$ & $(0.415)$ \\
\hline \multicolumn{7}{|c|}{ Political party membership (omitted category: no party membership) } \\
\hline \multirow{3}{*}{$\begin{array}{l}\text { Communist Party of } \\
\text { China }\end{array}$} & & & & & & \\
\hline & 0.287 & -0.546 & 0.158 & -0.112 & -0.021 & -0.065 \\
\hline & $(0.223)$ & $(0.720)$ & $(0.146)$ & $(0.190)$ & $(0.092)$ & $(0.227)$ \\
\hline \multirow[t]{2}{*}{ Democratic Party } & $0.829 * *$ & 1.497 & 0.301 & 0.408 & $0.573 * * *$ & -0.579 \\
\hline & $(0.384)$ & $(1.959)$ & $(0.279)$ & $(0.600)$ & $(0.156)$ & $(0.522)$ \\
\hline \multirow[t]{2}{*}{ Missing information } & 0.570 & -1.628 & 0.097 & -0.334 & -0.057 & -0.253 \\
\hline & $(0.650)$ & (1.256) & $(0.398)$ & $(0.325)$ & $(0.274)$ & $(0.398)$ \\
\hline
\end{tabular}

Pressure at the establishment level

Trade union at firm (omitted category: don't have)

$\begin{array}{lcccccc}\text { Have } & 0.904 * * * & 1.950 * * & 0.523 * * * & 0.493 * * & 0.046 & 0.083 \\ & (0.252) & (0.765) & (0.154) & (0.201) & (0.106) & (0.237) \\ \text { Missing information } & -4.644 & 3.620 & -34.747 & 0.845 & -0.890 & 0.205 \\ & (6.175) & (7.617) & (1692.496) & (1.591) & (2.365) & (1.868)\end{array}$


Communist Party organization at the firm (omitted category: don't have)

Have

$\begin{array}{llllll}0.720 * * * & 2.334 * * & 0.475 * * * & 0.719 * * * & 0.230 * * & 0.146 \\ (0.249) & (0.920) & (0.169) & (0.261) & (0.102) & (0.261)\end{array}$

Control variables: other characteristics of private firms

Year of registration (omitted category: 2001+)

\begin{tabular}{|c|c|c|c|c|c|c|}
\hline \multirow[t]{2}{*}{-1991} & $1.661 * * *$ & 0.361 & $1.236 * *$ & 0.357 & $0.405^{*}$ & 0.312 \\
\hline & $(0.597)$ & $(3.025)$ & $(0.618)$ & $(0.946)$ & $(0.233)$ & $(0.792)$ \\
\hline \multirow[t]{2}{*}{ 1992-2000 } & $0.517 * *$ & 0.599 & 0.162 & 0.196 & $0.336 * * *$ & 0.046 \\
\hline & $(0.210)$ & $(0.723)$ & $(0.138)$ & $(0.195)$ & $(0.087)$ & $(0.218)$ \\
\hline \multirow[t]{2}{*}{ Missing information } & -0.221 & 2.105 & -0.433 & 0.586 & $0.564 * * *$ & $0.975 * *$ \\
\hline & $(0.454)$ & $(1.533)$ & $(0.276)$ & $(0.414)$ & $(0.191)$ & $(0.463)$ \\
\hline
\end{tabular}

Family enterprise (omitted category: no)

$\begin{array}{lcccccc}\text { Yes } & 0.087 & 1.470 * * & 0.052 & 0.383 * * & 0.041 & 0.190 \\ & (0.259) & (0.711) & (0.173) & (0.184) & (0.106) & (0.231) \\ \text { Missing information } & -0.256 & 1.543 * & -0.095 & 0.423 * & 0.036 & -0.227 \\ & (0.372) & (0.894) & (0.240) & (0.233) & (0.155) & (0.285)\end{array}$

Sector (omitted category: manufacturing)

Mining, real estate and construction

$\begin{array}{rrrrrr}0.297 & 1.470 & 0.082 & 0.245 & 0.232 * & 0.837 * * * \\ (0.327) & (0.927) & (0.231) & (0.253) & (0.134) & (0.287)\end{array}$

Commerce and services

$\begin{array}{llllll}-0.195 & -1.766^{* *} & -0.088 & -0.444^{* * *} & -0.027 & 0.115 \\ (0.271) & (0.751) & (0.168) & (0.194) & (0.114) & (0.243)\end{array}$

Agriculture/forestry/animal husbandry/fishery

\begin{tabular}{|c|c|c|c|c|c|c|}
\hline & -0.298 & 0.628 & -0.111 & 0.216 & -0.045 & -0.269 \\
\hline & $(0.387)$ & (1.147) & $(0.270)$ & $(0.306)$ & $(0.158)$ & $(0.340)$ \\
\hline \multirow[t]{2}{*}{ Others } & -0.296 & 0.206 & -0.090 & 0.018 & $-0.256^{*}$ & 0.197 \\
\hline & $(0.313)$ & $(0.848)$ & $(0.193)$ & $(0.215)$ & $(0.132)$ & $(0.287)$ \\
\hline \multirow[t]{2}{*}{ Missing information } & -1.403 & 1.286 & $-1.212 * *$ & 0.211 & 0.018 & -0.380 \\
\hline & $(1.052)$ & (1.707) & $(0.581)$ & $(0.453)$ & $(0.466)$ & $(0.525)$ \\
\hline
\end{tabular}


Shareholders meeting (omitted category: don't have)

Have

$\begin{array}{llllll}-0.208 & -0.310 & -0.150 & 0.054 & 0.064 & 0.072 \\ (0.221) & (0.676) & (0.143) & (0.182) & (0.092) & (0.205)\end{array}$

Board of directors (omitted category: don't have)

Have

$\begin{array}{llllll}-0.109 & -1.013 & -0.171 & -0.282 & 0.305 * * * & 0.347 \\ (0.239) & (0.674) & (0.153) & (0.177) & (0.100) & (0.214)\end{array}$

Board of supervisors (omitted category: don't have)

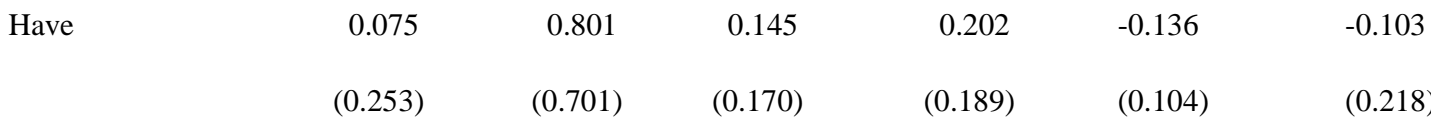

Control variables: other characteristics of private entrepreneurs

Gender (omitted category: male)

$\begin{array}{lllllll}\text { Female } & 0.518 * & -0.367 & 0.333^{*} & -0.012 & -0.016 & -0.485^{* *} \\ & (0.302) & (0.708) & (0.187) & (0.182) & (0.127) & (0.236)\end{array}$

Missing information

$\begin{array}{lrrrrr}1.027 & 2.008 & 1.136 & . & -0.005 & -0.927 \\ (1.838) & (5.342) & (1.290) & . & (0.768) & (1.364)\end{array}$

Age (omitted category: age $<=39$ )

$\begin{array}{lcccccc}40-50 & -0.330 & -0.435 & -0.296^{*} & -0.126 & -0.050 & 0.201 \\ & (0.285) & (0.637) & (0.176) & (0.162) & (0.119) & (0.210) \\ \text { Age }>=51 & -0.314 & -0.282 & -0.115 & -0.164 & -0.387 * * * & 0.437 * \\ & (0.324) & (0.799) & (0.205) & (0.210) & (0.135) & (0.259) \\ & & & & & & -0.604\end{array}$

Education (omitted category: Short)

$\begin{array}{lcccccc}\text { Middle } & 0.116 & 0.510 & -0.035 & 0.167 & 0.054 & 0.411 \\ & (0.399) & (0.950) & (0.235) & (0.242) & (0.170) & (0.316) \\ & 0.060 & 0.287 & -0.176 & 0.057 & 0.184 & 0.469 \\ \text { Long } & (0.390) & (0.914) & (0.233) & (0.234) & (0.166) & (0.304) \\ & -1.272 & 4.033^{*} & -1.039 * * & 1.019 * & 0.426 & -0.045 \\ \text { Missing information } & (0.804) & (2.099) & (0.432) & (0.544) & (0.359) & (0.621)\end{array}$

Previous occupation

Cadre (omitted category: haven't been) 


$$
\text { Yes }
$$

$$
\begin{array}{lll}
0.347 & 0.107 & 0.038 \\
(0.251) & (0.763) & (0.167)
\end{array}
$$

0.014

$0.293^{* * *}$

0.053

(0.763)

$(0.167)$

$(0.204)$

(0.103)

\begin{tabular}{|c|c|c|c|c|c|c|}
\hline Yes & 0.339 & 0.342 & 0.197 & 0.110 & 0.097 & -0.378 \\
\hline & $(0.364)$ & $(0.933)$ & $(0.240)$ & $(0.240)$ & $(0.151)$ & $(0.310)$ \\
\hline
\end{tabular}

$(0.233)$

Manager (omitted category: haven't been)

$\begin{array}{ccccccc}\text { Yes } & 0.310 & -0.261 & 0.216 & -0.038 & 0.006 & -0.194 \\ & (0.224) & (0.606) & (0.148) & (0.157) & (0.093) & (0.195)\end{array}$

Technician (omitted category: haven't been)

Worker (omitted category: haven't been)

\begin{tabular}{|c|c|c|c|c|c|c|}
\hline \multirow[t]{2}{*}{ Yes } & 0.074 & -0.631 & 0.042 & -0.121 & 0.043 & 0.045 \\
\hline & $(0.352)$ & $(1.020)$ & $(0.223)$ & $(0.266)$ & $(0.147)$ & $(0.328)$ \\
\hline
\end{tabular}

$\begin{array}{ccccccc} & 0.067 & -0.562 & 0.248 & -0.129 & -0.241 * * & 0.039 \\ \text { Yes } & (0.275) & (0.690) & (0.180) & (0.176) & (0.115) & (0.228)\end{array}$

Self-employed (omitted category: haven't been)

\begin{tabular}{|c|c|c|c|c|c|}
\hline Yes & 0.469 & -1.050 & 0.318 & -0.298 & 0.056 \\
\hline & $(0.296)$ & $(0.771)$ & $(0.200)$ & $(0.205)$ & $(0.122)$ \\
\hline
\end{tabular}

$\begin{array}{ccccccc}\text { Yes } & 0.553 * * & 1.206 * & 0.356 * * & 0.300 * & 0.022 & -0.118 \\ & (0.233) & (0.626) & (0.157) & (0.163) & (0.096) & (0.190)\end{array}$

Farmer (omitted category: haven't been)

Other occupation (omitted category: haven't been)

\section{Control variables: province information}

$\begin{array}{lcccccr}\text { Marketization index } & -0.093 & -0.556 & 0.014 & -0.185 & -0.117 & 0.029 \\ & (0.187) & (0.566) & (0.110) & (0.150) & (0.077) & (0.138)\end{array}$

Province (omitted category: Beijing)

\begin{tabular}{lllllll} 
& & 30 & & 30 & & 30 \\
Constant & 30 provinces & provinces & 30 provinces & provinces & 30 provinces & provinces \\
& 2.323 & 0.069 & -0.995 & 0.131 & $8.510^{* * *}$ & $6.395 * * *$ \\
Sigma & $(1.771)$ & $(4.917)$ & $(1.061)$ & $(1.327)$ & $(0.785)$ & $(1.197)$ \\
& $4.452 * * *$ & $7.824 * * *$ & & & & \\
\hline $\mathrm{N}$ & $(0.077)$ & $(0.275)$ & & & & \\
\end{tabular}




\begin{tabular}{lllll} 
Pseudo R2 & 0.0587 & 0.1029 & & \\
LR chi2 (71) & 751.65 & 526.02 & & \\
Prob > chi2 & 0.0000 & 0.0000 & 0.359 & 0.423 \\
adj. R ${ }^{2}$ & & & 15.989 & 6.800 \\
F & & & \\
\hline \hline
\end{tabular}

\section{Note:}

1): Source: Authors' estimates from The Tenth National Sample Survey on China's Private Enterprises in 2012.

2) Standard errors in parentheses; ${ }^{*} \mathrm{p}<0.1, * * \mathrm{p}<0.05$, *** $\mathrm{p}<0.01$;

3) Only includes the observations for companies whose net profits are above 0;

4) "People's Congress" is shortened as "PC"; "Chinese People's Political Consultative Conference" is shortened as "CPPCC"; 
Table 5: A robustness check

\begin{tabular}{|c|c|c|c|c|c|c|}
\hline & \multicolumn{2}{|c|}{ Tobit } & \multicolumn{2}{|c|}{ Logit } & \multicolumn{2}{|c|}{ OLS } \\
\hline & ACFIC & SAIC & ACFIC & SAIC & ACFIC & SAIC \\
\hline \multicolumn{7}{|c|}{ Ln (net profit of enterprise per year) } \\
\hline \multirow[t]{2}{*}{ (unit: 10000 Yuan ) } & $0.857 * * *$ & $1.276 * * *$ & $0.301 * * *$ & $0.253 * * *$ & $0.493 * * *$ & $0.518 * * *$ \\
\hline & $(0.058)$ & $(0.153)$ & $(0.037)$ & $(0.037)$ & $(0.024)$ & $(0.049)$ \\
\hline \multicolumn{7}{|c|}{ Membership in PC or CPPCC (omitted category: not a member of PC or CPPCC) } \\
\hline \multirow[t]{2}{*}{ Membership in PC } & $1.731 * * *$ & $4.054 * * *$ & $0.750 * * *$ & $1.027 * * *$ & $0.496 * * *$ & 0.272 \\
\hline & $(0.282)$ & $(1.023)$ & $(0.186)$ & $(0.272)$ & $(0.116)$ & $(0.270)$ \\
\hline \multirow[t]{2}{*}{ Membership in CPPCC } & $2.160 * * *$ & $5.343 * * *$ & $1.115^{* * *}$ & $1.366 * * *$ & $0.420 * * *$ & $0.467 * *$ \\
\hline & $(0.237)$ & $(0.911)$ & $(0.150)$ & $(0.246)$ & $(0.099)$ & $(0.238)$ \\
\hline \multicolumn{7}{|c|}{ Political party membership (omitted category: no party membership) } \\
\hline \multirow[t]{2}{*}{ Communist Party of China } & 0.207 & -0.453 & 0.128 & -0.091 & -0.062 & -0.043 \\
\hline & $(0.226)$ & $(0.743)$ & $(0.142)$ & $(0.180)$ & $(0.093)$ & $(0.222)$ \\
\hline \multirow[t]{2}{*}{ Democratic Party } & 0.607 & 0.828 & 0.183 & 0.268 & $0.557 * * *$ & -0.837 \\
\hline & $(0.387)$ & $(2.062)$ & $(0.269)$ & $(0.598)$ & $(0.156)$ & $(0.520)$ \\
\hline \multicolumn{7}{|c|}{ Trade union at firm (omitted category: don't have) } \\
\hline Have & $0.855^{* * *}$ & $2.026^{* *}$ & $0.448 * * *$ & $0.471 * *$ & 0.048 & 0.009 \\
\hline
\end{tabular}


Communist Party organization at the firm (omitted category: don't have)

Have

$0.677 * * *$

$2.692 * * *$

(0.942)

$(0.251)$

$0.470 * * *$

$0.758 * * *$

0.167

0.264

(0.244)

$(0.103)$

(0.254)

Note:

1) Compared to the base model, there are no province dummies in the independent variables in this alternative specification...

2) In the base model shown in Table 4, there are two independent variables that capture province information. One is the "marketization index" and the others are 30 provincial dummy variables. We were worried that there might be some correlation between the two independent variables, so as a robustness check we included only the continuous "marketization index" but excluded the 30 provincial dummies.

3) "People's Congress" is shortened as "PC"; "Chinese People's Political Consultative Conference" is shortened as "CPPCC".

4) The coefficients of the other control variables are not shown in this table. 
Figure 1: The cumulative amount of donations by ACFIC and SAIC firms in the year 2011

\section{Figure 1}

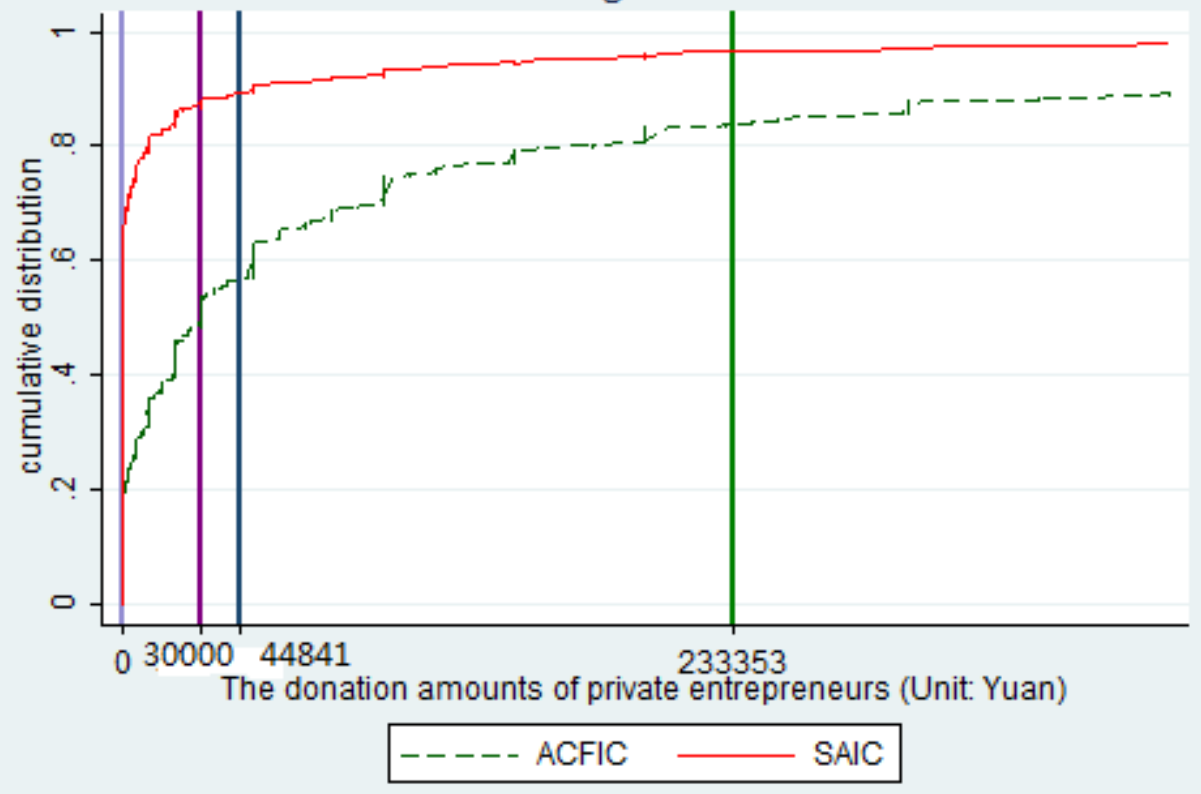

Note:

1) Source: Authors' computations from The tenth National Sample Survey on China's Private Enterprises in 2012.

2) The figure shows the cumulative amount of donations and includes observations with zero donations.

3) In the ACFIC sample, the median of donations is 30000 and the mean of donations is 233 353; In the SAIC sample, the median of donations is 0 and the mean of donations is 44841 . 
Figure 2: The relationship between private enterprises' net profits and donations in 2011

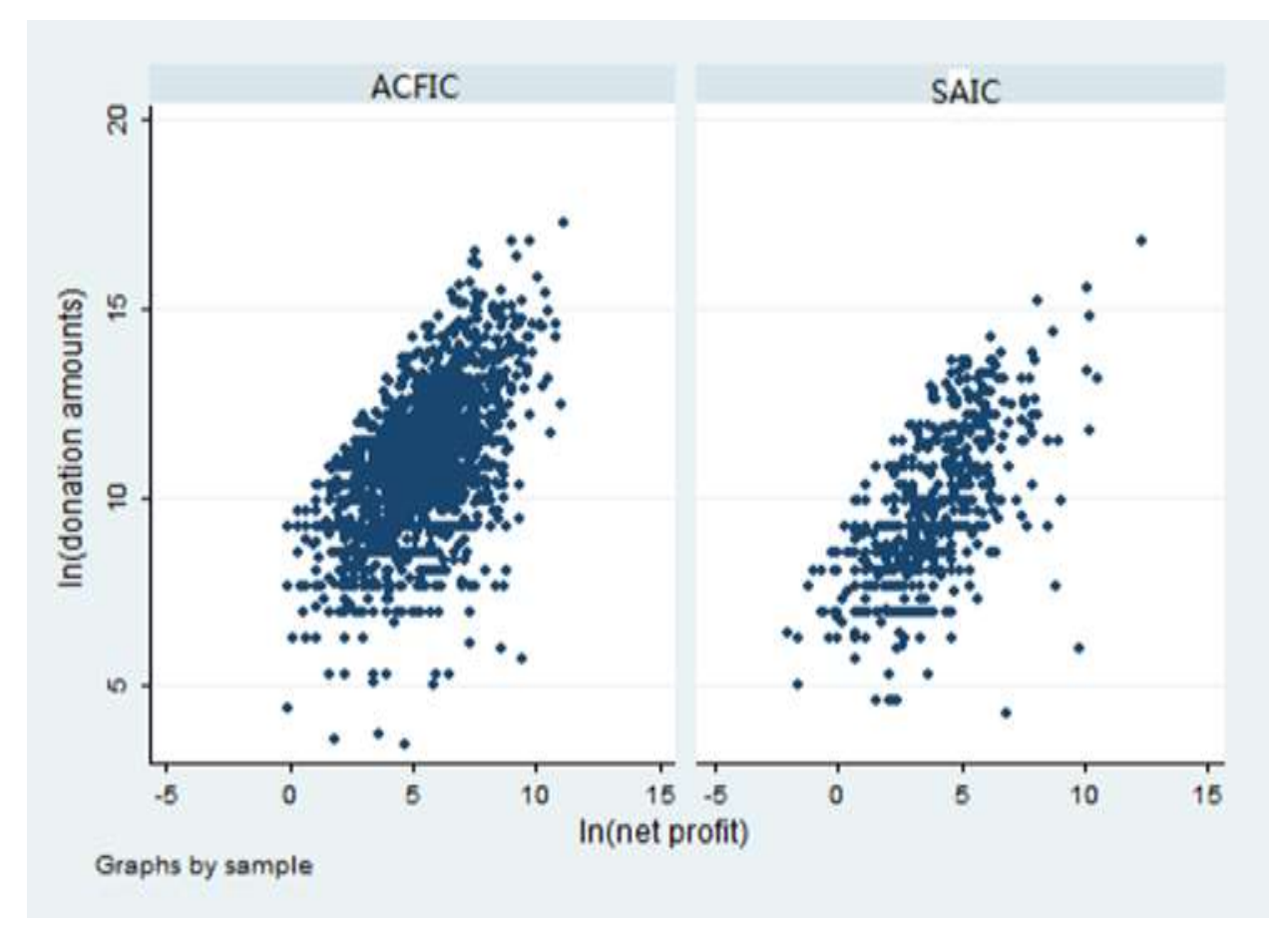

Note:

1) Source: Authors' computations from The tenth National Sample Survey on China's Private Enterprises in 2012.

2) The results were obtained by analyzing those companies whose net profit was above zero and whose donation amount was also above zero. 
Appendix. Membership and non-membership in bridging organizations crossed with membership in political parties

a) Members and non-members distribution by PC and, CPPCC status

ACFIC sample

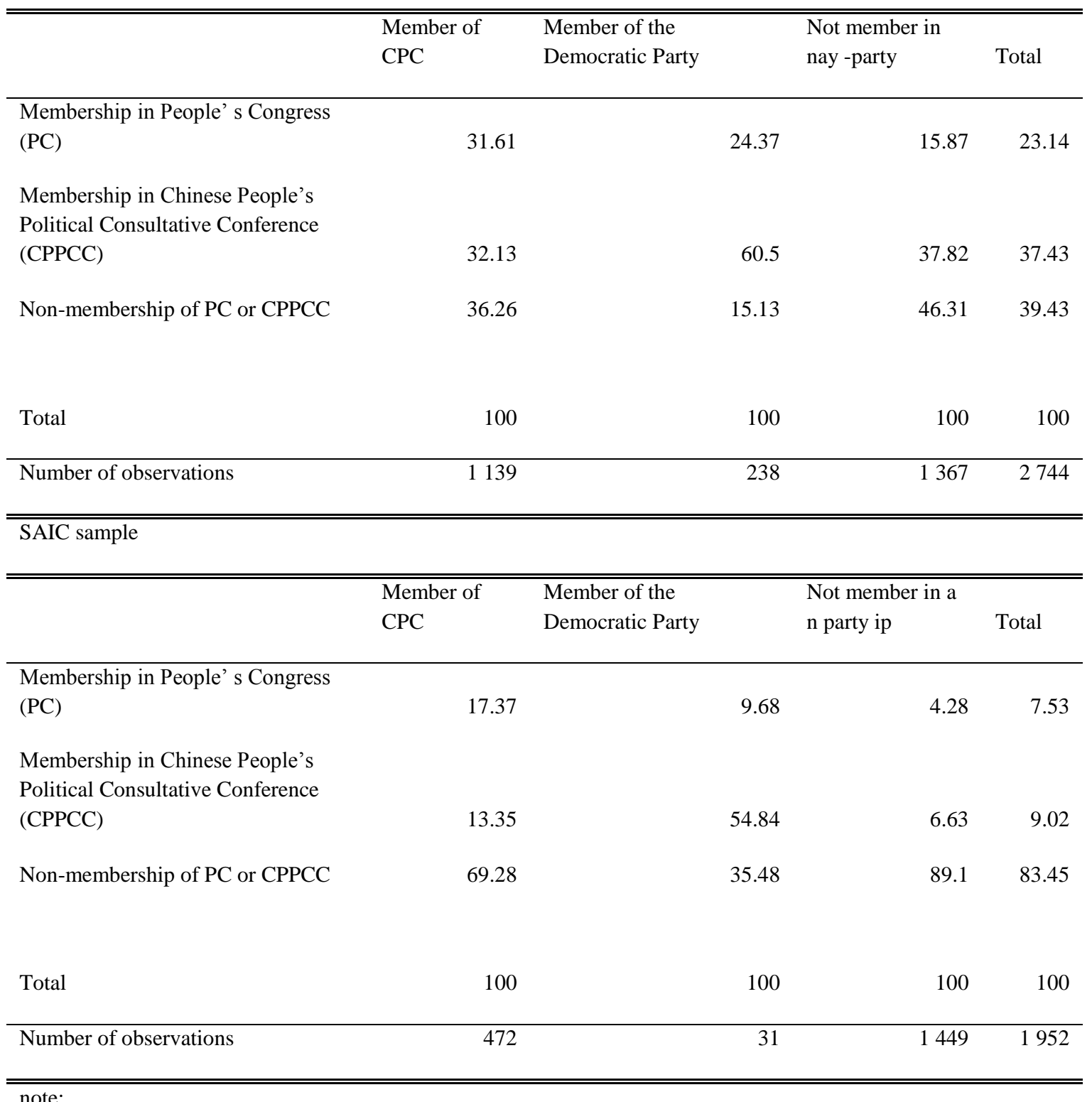

1) People can't be members of both PC and CPPCC at the same time. They only can choose one of them. 
b) PC and CPPCC by Party member status

ACFIC sample

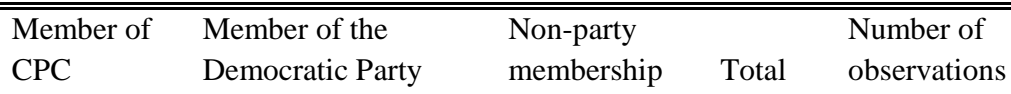

Membership in People's

Congress (PC)

56.69

9.13

34.17

100

635

Membership in Chinese

People's Political

Consultative Conference

(CPPCC)

35.64

14.02

$50.34 \quad 100$

1027

Non-membership of PC or

CPPCC

38.17

3.33

58.5

100

1082

Total

41.51

8.67

$49.82 \quad 100$

2744

SAIC sample

\begin{tabular}{|c|c|c|}
\hline $\begin{array}{l}\text { Member of } \\
\text { CPC }\end{array}$ & $\begin{array}{l}\text { Member of the } \\
\text { Democratic Party }\end{array}$ & $\begin{array}{l}\text { Non-party } \\
\text { membership }\end{array}$ \\
\hline
\end{tabular}

Membership in People's

Congress (PC)

55.78

2.04

42.18

100

147

Membership in Chinese

People's Political

Consultative Conference

(CPPCC)

35.8

9.66

54.55

100

176

Non-membership of PC or

CPPCC

20.07

0.68

79.25

100

1629

Total

24.18

1.59

74.23

100

1952 